\title{
PEDAGOGICAL CONDITIONS OF FUTURE VETERINARIAN'S PREPARATION FOR PROFESSIONAL COMMUNICATION
}

The article deals with the pedagogical conditions of future veterinarian's preparation for professional communication. The essence of the term "condition" is clarified. The essence and structure of communicative readiness of the future veterinarian, which consists of motivational, content and operational and procedural components, are determined. Communicative preparation of specialists is a complex multidimensional process that depends on a set of pedagogical conditions that ensure the realization of all its components. It has been found out that the specificity of the veterinarian's professional communication is to solve problems and tasks that are relevant to their profession. It is emphasized that the professional orientation of the future veterinarian's personality implies understanding and internal acceptance of the goals and tasks of professional activity. Pedagogical conditions are an important component of preparation for professional communication. The system of communicative, linguistic and tactical knowledge is of great importance for developing the content of future specialist's preparation for professional communication. The process of teaching professional communication involves the presence of a certain communication space, which is the basic concept for analysing the process of communication.

Important forms of organizing students'educational activities for the purpose of developing their professional language are considered. It is stated that the level of students' readiness to acquire knowledge in the specialty with the help of necessary communication skills is achieved by applying a holistic system of criteria for selection of content and technology for forming professional language in Ukrainian. The logical sequence of the selection and justification of the stages and methods of development of professional communication of specialists is determined.

The set of pedagogical conditions concerning preparation of the future veterinarian for professional communication is defined. The proposed pedagogical conditions are closely interconnected, reflecting and realizing the target, content and procedural components of future veterinarian's preparation for professional communication in the process of studying the humanities. The need to prepare future veterinarians for professional communication is driven by objective needs for competitive personnel that meet world standards.

Key words: conditions, pedagogical conditions, preparation, professional communication, specialist, veterinarian.

Statement of the problem. The modern stage of society development puts forward fundamentally new requirements for the work of professionals, and therefore for the work of higher education institutions engaged in their preparation. The professional activity of the future specialist has its own specific features and provides for special conditions of readiness formation to perform functional duties. The success and effectiveness of professional communication formation of future veterinarians depends on the set of adequate principles, functional orientation of training, methods and techniques, means and pedagogical conditions under which training will be organized.

At the stage of reforming the modern high school in pedagogical research related to the problems of improving the functioning of pedagogical systems and increasing the efficiency of the educational process, one of the most interesting aspects is the identification, substantiation and verification of pedagogical conditions that ensure the future activity.
Analysis of previous research and publications. Scholars who have dealt with the issues of determining pedagogical conditions in different aspects of pedagogical science are: N.V. Ippolitova, N.A. Sterikhova, O.M. Horodyska, N.V. Kuzmina, O.M. Belkin, V.M. Nesterov, V.I. Andreev and others. Communicative preparation of future veterinarians is a complex multidimensional process that depends on a set of pedagogical conditions that ensure the implementation of all its components.

The purpose of the article. The main purpose of this work is to define a set of pedagogical conditions of future veterinarian preparation for professional communication. Achieving this goal requires a number of important tasks, in particular, clarifying the essence of the concepts of "professional communication of the future specialist".

Presentation of main material. The concept "condition" in modern scientific literature is interpreted as "environment", "state", "circumstances" necessary for the emergence, development and change of the pedagogical system. In pedagogical dictionary 
by V.I. Zahviazinskyi, in addition to the "stimulating environment", the conditions include causes, factors of development, technologies, methods, teaching, training and development, administrative support, etc. [4]. Scientists who study language education, N.V. Dvornikova, O.V. Nazola, N.V. Sheremetova, S.A. Khazova and others, consider pedagogical conditions as a set of objective and subjective factors on which the purpose of the educational process depends. Researchers I.H. Hlukhov and T.A. Shmonina, summarizing the opinions of scientists, note that "pedagogical conditions" are a qualitative characteristic of the main factors, processes and phenomena of the educational environment, which purposefully created and implemented in the educational environment and provide solutions to the task set [7, p. 65-68].

Agreeing with the definition of the essence and content of the concept of "pedagogical conditions", we note that in the agricultural university system of measures of educational process, which provides the creation and development of personal motives for students to study and organize the nature of their educational and cognitive activities with orientation aimed at achieving the goal.

At the present stage of mastering future specialists, a high level of professional and communicative skills is considered as a prerequisite for intellectual development of a person with higher education. The specificity of the veterinarian's professional communication is that the participants in the dialogue or the polylogue try to solve problems and tasks that are relevant to their profession. Therefore, under the professional communication of a veterinarian, we understand the speech interaction of a specialist in agriculture with colleagues, partners, and customers of the institution in terms of professional activity. The status of each of the interlocutors in this interaction is clearly defined, and the process of communication itself is the solution of production issues by means of influencing the views, emotions or behaviour of communicators and is carried out in accordance with the functions and goals [8, p. 34].

The current state of communication readiness of future veterinarians cannot fully satisfy the need of society for specialists with high level of professional and communicative competence. Unfortunately, a large number of higher education institutions of the agricultural profile continue to focus on the complex of professional disciplines, which, in their opinion, determine the content of vocational training, while not paying due attention to the discipline of the humanities. However, in accordance with the requirements of the Bologna Convention and the pan-European Guidelines for the Humanities, the scientific and pedagogical staff of the agricultural profile institution must develop and improve such integrated curricula and programmes that can prepare a specialist capable of applying their knowledge and results to the theoretical and practical research, formulate recommendations for the improvement of veterinary sciences, etc.

There is no single approach to determine the content and structural components of readiness for a particular activity. S.H. Vorobiova, in particular, proposes to determine the structural elements of students' readiness for creative solution of didactic tasks in the unity of four components:

- motivational (beliefs, views, motives, attitudes to certain behaviour);

- personal (feelings, intellectual qualities);

- content (knowledge);

- professional (skills) [2, p. 43].

An important component of the future veterinarian's preparation for professional communication is a set of pedagogical conditions that contribute to the organization of an effective pedagogical process in the university of agricultural and economic profile and its implementation. The core value of personally-oriented pedagogical technologies is a personal approach that integrates and embodies ideas of future professional's preparation, such as harmonious personality development, axiology of pedagogical relationships as the basis for the formation of a democratic and full-featured personality. Among the principles of implementing a personal approach are:

- constant study and excellent knowledge of the characteristics of the student's personality;

- ability of a teacher of a higher educational institution to diagnose the real level of skills and personal qualities formation;

- prompt change of tactics of interaction with the student depending on new conditions and circumstances;

- maximum reliance on the own activity of the teacher's personality;

- creation of conditions for independence, initiative, ability to direct activities that lead to success [1, p. 15].

The specificity of the professional orientation of the interests and preferences of the future veterinarian's personality during university study is that this process is done purposefully, systematically and gradually through the study of the disciplines of the veterinary and humanitarian cycle. Therefore, there is an objective need to conduct a series of studies in the university in order to study the interests and requests of future veterinarians and to determine on this basis a methodology for the formation of socially motivated professional orientation, which will be of value to the individual and society as a whole.

The professional orientation of the future veterinarian's personality implies understanding and internal acceptance of the goals and objectives of the professional activity, as well as the interests, 
attitudes, beliefs and views that are consistent with it. In order to help future specialists in the agricultural profile develop their professional motives during their studies at the university, teachers need to help them to form a correct understanding of the social importance and content of the future profession, to strengthen professional self-esteem, confidence in the successful mastery of the profession. However, according to V.A. Semychenko, the first priority in the process of future specialist's preparation should be the development of the student's own personality, and the next step is his professionalization and specialization [5].

The basis of the future veterinarians preparation for professional communication is the logic of selecting the content of training in the following sequence: from the communicative aspect (selection of topics and situations of communication) to linguistic (selection of texts and language inventory) and to the completion of procedural and psychophysiological (selection of knowledge, skills, which must be mastered to form communicative competence) [6]. Communication system (knowledge about ways of establishing and maintaining contact with the interlocutor and strategies of speech interaction; about the variety of communicative techniques and methods, their influence on the communicative activity of people, and ways of constructing a logical structure is important for developing the content of future specialists preparation for professional communication), linguistics (knowledge of the language system and its rules, styles of speech and their features, linguistic material that predict the successful development of communication) and provide speech skills (knowledge of phonetic and spelling features of the language, knowledge of the correct use of language in a particular communication situation, knowledge of speech stereotypes that the speaker uses to interact).

The process of professional communication teaching involves the presence of a certain communication space, which is the basic concept for analysing the process of communication. The communicative space is a complex formation, which is characterized by a certain system, and therefore it is characterized by such systemic properties as integrity (a measure of communicative equilibrium), structural (volume, intensity and complexity of the relationship between components), autonomy of structural components (determination of the place of each component in the system of communication process, as well as the number of possible free choice steps that the communication subjects have in choosing the means and methods of transmission information and the goal of communication) [3].

Thus, on the basis of psychological and pedagogical literature, we have identified the following pedagogical conditions for the preparation of future specialists in agriculture:
- formation of positive motivation through the implementation of a person-centred approach (contributes to the increase of cognitive activity, actualization of the need for mastering the skills of interpersonal communication interaction);

- providing the logic of constructing the content of training in the sequence of communicative, linguistic, procedural, psychophysiological elements (contributes to the sequence of selection of topics and situations, knowledge and skills as prerequisites for effective formation of communicative competence);

- organization of educational communicative space and modelling of communicative situations of a professional nature (promotes intensification of the educational process, activation of the student's communication potential, formation of communicative experience);

- mastering the integrated content of the special course based on the ideas of contextual learning (contributes to ensuring the consistency, the stages of communication between thehumanitiesandspecialized disciplines, their effectiveness and efficiency).

In order to realize the first pedagogical condition of the future veterinarians preparation for professional communication in the process of studying the humanities, it is necessary to diagnose the characteristics of the student audience; to create a positive emotional background in practical classes through the use of exercises, role-playing and business games, the topics of which are relevant for future professionals in agriculture; development of skills to apply the acquired knowledge and acquire new knowledge necessary for the innovative activity of the economy, etc.

In order to realize the second pedagogical condition (providing logic for constructing the content of learning in the sequence of communicative, linguistic, procedural, psychophysiological elements), work with students should be organized in order to transform their acquired communication skills into competencies that will promote the ability to choose optimal behaviour strategies in one or another situation of professional activity, to direct the professional skills to achieve certain goals, to establish an effective business management system, etc.

For the realization of the third pedagogical condition (organization of educational communicative space and modelling of communicative situations of professional content) it is necessary to ensure the connection of subjects of educational programmes of disciplines of the humanities cycle with typical situations of professional activity of veterinarian, where the prerequisite for the effective fulfilment of the tasks will be the level of formation of professional communication skills, which will enhance the communication potential and communicative consciousness of the future specialist, intensify the process of information exchange, communicative comfort, etc. 
In order to realize the fourth pedagogical condition (mastering the integrated content of a special course based on the ideas of vocational training), the concept of working with students should be based on the need to model the subject and social content of professional communication, to modernize approaches to the formation of linguistic personality of the university as a future active participant in national and international projects.

Conclusions and suggestions. Therefore, pedagogical conditions (formation of positive motivation through the implementation of a personally oriented approach; providing logic for constructing the content of education in the consistent unity of communicative, linguistic, procedural, psychophysiological elements; organization of educational communicative space and modelling of communicative situations of a professional nature; mastery of the integrated content of a special course based on ideas of contextual learning) are closely interconnected, reflecting and realizing the destination, substantive and procedural components of the future veterinarians preparation for professional communication in the process of studying the humanities. Prospects for further research are to develop a technology for the formation of a foreign professional competence of a future specialist.

\section{References:}

1. Викулина М.А. Личностно-ориентированная подготовка студентов в педагогическом вузе (основы теории) : монография. Нижний Новгород : Нижегород. гуманитар. центр, 2000. 136 с.

2. Воробйова С.Г. Структура, критерії і рівні готовності студентів до творчого рішення дидактичних задач. Рідна школа. 2002. № 4. С. 42-45.

3. Орбан-Лембрик Л.Е. Соціальна психологія особистості і спілкування. Соціальна психологія : підручник : у 2 кн. Кн. 1. Київ : Либідь, 2004. 576 с.

4. Педагогический словарь : учебное пособие для студентов высшего учебного заведения / под ред. В.И. Загвязинского, А.Ф. Закировой. Москва : Академия, 2008. 352 с.

5. Семиченко В.А. Пути повышения эффрективности изучения психологии. Киев : Магістр-S, 1997. 124 c.

6. Тарнопольский О.Б. Методика обучения английскому языку делового общения : учебное пособие / О.Б. Тарнопольский, С.П. Кожушко. Киев : Ленвит, 2004. 191 с.

7. Шмоніна Т.А. Сучасні підходи до розуміння поняття «педагогічні умови». Збірник наукових праць. Педагогічні науки / Т.А. Шмоніна, І.Г. Глухов. Вип. 59. Херсон : ХДУ, 2011. С. 65-68.

8. Ярощук І.Д. Підготовка майбутніх економістів до професійного спілкування у процесі вивчення гуманітарних дисциплін : дис. ... канд. пед. наук : 13.00.04. Тернопіль, 2010. 250 с.

9. Horn R.C. On professions, professionals, and professional ethics. Malvern, Pn. : American Institute for Property and Liability Underwriters, 1978. $71 \mathrm{p}$.

Стукало О. Педагогічні умови підготовки майбутніх ветеринарів до професійного спілкування

У статті розглядаються педагогічні умови підготовки майбутніх ветеринарів до професійного спілкування. З'ясовано суть поняття «умова». Визначено суть і структуру комунікативної готовності майбутнього ветеринара, яка складається з мотиваційного, змістового та операційно-процесуального компонентів. Комунікативна підготовка фрахівців - це складний багатоаспектний процес, що залежить від комплексу педагогічних умов, які забезпечують реалізацію усіх їі компонентів. З'ясовано, що специфіка професійного спілкування ветеринара полягає в розв'язанні проблем і завдань, які актуальні для їхньої професії. Наголошено, що професійна спрямованість особистості майбутнього ветеринара передбачає розуміння та внутрішнє прийняття ним цілей і завдань профресійної діяльності. Педагогічні умови є важливим компонентом підготовки фахівиів до профресійного спілкування. Вагоме значення для розробки змісту підготовки майбутніх фрахівців до профресійного спілкування має система комунікативних, лінгводидактичних і мовленнєвих знань. Процес навчання профресійного спілкування передбачає наявність певного комунікативного простору, який є базовим поняттям для аналізу процесу спілкування.

Розглянуто важливі форми організації навчальної діяльності студентів з метою розвитку їхнього профресійного мовлення. Зазначено, що рівень готовності студентів до засвоєння знань зі спеціальності за допомогою необхідних комунікативних умінь досягається застосуванням цілісної системи критеріїв відбору змісту й технологї формування профресійного мовлення українською мовою. Визначена логічна послідовність відбору й обґрунтування етапів і методів розвитку профресійного мовлення фрахівців. Важливим фрактором ефективності формування профресійного мовлення є визначення їі адекватності змісту.

Визначено комплекс педагогічних умов щодо підготовки майбутнього ветеринара до профресійного спілкування. Запропоновані педагогічні умови перебувають у тісному взаємозв'язку, показують і реалізовують цільовий, змістовий і процесуальний компоненти підготовки майбутніх ветеринарів до професійного спілкування в процесі вивчення гуманітарних дисциплін. Необхідність підготовки майбутніх ветеринарів до професійного спілкування зумовлена об'єктивними потребами в конкурентоспроможних кадрах, які відповідають світовим стандартам.

Ключові слова: умови, педагогічні умови, підготовка, профресійне спілкування, фрахівець, ветеринар. 